\section{The heat of competition}

ONE should not forget that the republican spirit is alive and well in France, more than 200 years after the French Revolution. The grandest people are called "monsieur", as in "Monsieur le Président". And some of the grandest people every day shake hands with those who sit outside their doors, letting through those with appointments and diverting others elsewhere.

Another practical consequence is the institution of the concours - the system of competitive examinations by which people compete for places in the public service (which includes student places at the grandes écoles, whose concours are anonymous - see page 135) throughout France. The objective is to banish nepotism. One Briton working at an INSERM laboratory fulsomely admires the system, which he says should be adopted everywhere.

But there are obvious drawbacks for the management of laboratories. In CNRS, for example, the competition for places (held twice a year) means that particular laboratories cannot be sure that promising PhDs whom they would wish to fill particular slots will succeed in the national competition for places at the first, or second or even umpteenth attempt. Successful directors must have a supply of soft money (perhaps from industrial contracts) up their sleeves.

Promotion is also determined by concours - and the chance of success by the low ratio of vacancies to applicants. The obstacles to promotion to the status of directeur de recherche (group leader) is one of the chief discontents of young research workers in the public service.

The tendency towards centralism in France, everywhere apparent, also has other origins, mostly Napoleonic. The disadvantages of centralism have traditionally been freely acknowledged, but people have then shrugged their shoulders as if to say that little can be done about them. One of the achievements of the second Mitterrand presidency is that the cosy conventions of centralism are being eroded. The calculation seems to be that French economic growth will be faster if devolution gives regions an influence on their own welfare. That seems to be correct in the case of at least one region in the southwest (see page 131).

But decentralization is being worked out in a centralist fashion; there are the same rules for all the regions, while the devolution of responsibility for education, planning and economic development is far from complete. But in the long run, regional involvement in educational matters could be crucial for research.

\title{
"We want to play the game"
}

Director J. C. Duplessey at the CNRS Radioactive Tracer Laboratory (Institut des Faibles Radioactivités) tells how, when he published his first paper in an English-language US journal in 1971, his professor told him that he had been stupid. "Nobody will read it", he was told. But now the boot is on the other foot. "We want to play the game, and we have learned how to do it."

Where and how to publish is on everybody's mind, but there seems only one answer: in English, and in an international journal. The apparently serious suggestions of a few years ago that people's performance should be determined by a points system, with so many points for a paper in journal $X$, and so many fewer for a paper in journal $\mathrm{Y}$, have mercifully now been dropped. But there is a general understanding that there is no general case for publishing in French in a Frenchlanguage journal. Then you will not be read by the people you need to reach.

Nor will you be respected by your colleagues and compatriots. The annual reports of many public laboratories include not merely lists of the papers published during the past year, but an analysis of the proportion appearing in foreignlanguage journals (see, for example, the figure below).

Yet as things are, the change of practice seems to have made little impact on the bibliometric statistics. Recently published figures suggest that between 1981 and 1986 inclusive, the French share of the world's literature fluctuated narrowly and, if anything, that it declined (Martin et al. Science and Public Policy 17, 14-26; February 1990). In 1981, the French share of publications in the US National Science Foundation's file of journals was 5.02 per cent, but had declined to 4.84 per cent in 1984 , rising to 4.87 per cent in 1988 . (The corresponding figures for the United Kingdom are 8.34 per cent, 8.16 per cent and 8.19 per cent.)

No doubt these figures should be regarded with caution. For one thing, they are inevitably out of date. For another, there is plenty of anecdotal evidence - references to outstanding French papers in well-known journals - to suggest that the benefits of the new attitude towards publication have not yet worked their way through. There is also some weight in the observation of one laboratory director that it was fruitless to go looking for evidence of a resurgence of French science "when we may simply have started publishing in English". But the habit has come to stay.

That the French reputation for chauvinism should be so directly belied is proof of a profound sea-change of opinion, linked with a general appreciation that even the French government's generosity towards research will not enable France to make its own way in a competitive world without external collaboration. So people are also forever on the lookout for opportunities for collaboration, perhaps by the judicious placing of postdoctoral fellows in overseas laboratories, perhaps through collaborations with opposite numbers elsewhere and also through the European Communities.

But compliance does not mean pleasure. For one thing, there are practical difficulties. People whose mothertongue is French do not write easily in English. (This may be one explanation for the good sprinkling of English-speakers, American or British, in the public labora-

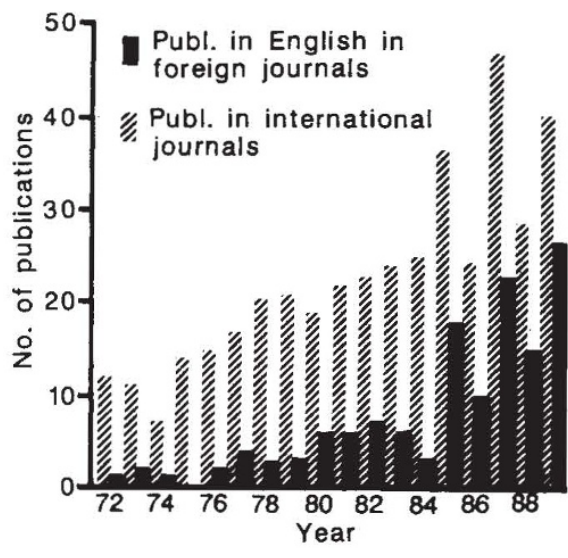

tories.) More contentiously, it is also asserted that French is intrinsically more capable of clarity - which may be another way of saying the same thing.

In any case, most people seem to hold that while English is now the language in which they must write papers - as it has also become a passable lingua franca of conversation - it will be a matter of great regret if French is altogether abandoned. Philip Lazar, the reflective directorgeneral of INSERM, says he hopes that "the time will never come when no science is written in French".

Nor need it. In contrast with those of the English-speaking world, French researchers still regard the production of books as an honourable occupation. Journals such as La Recherche, whose strong suit is high-level popularization, appear to be as much a pleasure to write for as they are to read. And the general popularity of technology as well as the need for interprofessional communication has been a powerful impetus for French technical publishing at all levels.

Yet the clinching sign that the use of English has come to stay must be that the Comptes Rendues de l'Academie des Sciences now precedes everything it publishes with an extended abstract in English. 